Relations industrielles

Industrial Relations

\title{
Report of the Royal Commission on Trade Unions and Employers Association (Donovan)
}

Volume 23, numéro 4, 1968

URI : https://id.erudit.org/iderudit/027959ar

DOI : https://doi.org/10.7202/027959ar

Aller au sommaire du numéro

Éditeur(s)

Département des relations industrielles de l'Université Laval

ISSN

0034-379X (imprimé)

1703-8138 (numérique)

Découvrir la revue

Citer cet article

(1968). Report of the Royal Commission on Trade Unions and Employers Association (Donovan). Relations industrielles / Industrial Relations, 23(4), 686-698. https://doi.org/10.7202/027959ar

Tous droits réservés (C Département des relations industrielles de l'Université Laval, 1968
Ce document est protégé par la loi sur le droit d'auteur. L'utilisation des services d'Érudit (y compris la reproduction) est assujettie à sa politique d'utilisation que vous pouvez consulter en ligne.

https://apropos.erudit.org/fr/usagers/politique-dutilisation/ 


\section{Report of the Royal Commission on Trade Unions and Employers Associations (Donavan)}

In April 1965, the British Government appointed a Royal Commission on Trade Unions and Employers Associations under the chairmanship of the Right Honourable Lord Donavan. The other members were : Professor Hugh Clegg, Professor of Industrial Relations, Warwick University, Lord Collison, C.B.E., General Secretary of the National Union of Agricultural Workers, Dame Mary Green, D.B.E., Headmistress, Kidbrooke School, Professor Otto Kahn-Freund, Professor of Comparative Law, Oxford University, Sir George Pollock, Q.C., former director of the British Employers' Confederation, The Rt. Hon. Lord Robens, Chairman, National Coal Board, Mr. Andrew Shonfield, Director of Studies, Royal Institute of International Affairs, Lord Tangley, K.B.E., Solicitor and Chairman or Director of a number of companies, Mr. John Thomson, T.D., Chairman of Barclay's Bank, Mr. Eric Wigham, C.B.E., Labour Correspondent, The Times, The Rt. Hon. George Woodcock, C.B.E., General Secretary, T.U.C.

The Commission received evidence from some 430 organisations and persons or groups of persons, and met on 128 days in all. The main evidence has already been published. The Commission has also published 11 research papers, and presented its Report in June 1968. The text of the report itself contains about 145,000 words. Certain members have added supplementary notes, and there are 9 appendices. Here is a summary of the Report.

\section{THE BACKGROUND}

The Commission was appointed, under the Chairmanship of Lord Donovan, in April 1965 to consider relations between managements and employees and the role of trade unions and employers' associations in promoting the interests of their members and in accelerating the social and economic advance of the nation, with particular reference to the law affecting the activities of these bodies, and report.

It was the fifth such Commission in the last hundred years, the first having been appointed in 1871, and the others in 1874, 1891 and 1903.

Discussing the background against which the Commission surveyed its problems and reached its conclusions, the report points out that the impact of two world wars and changes associated with developing technology, increasing scale of industrial organization, growing wealth and greater Government intervention have contributed to a transformation of the social and economic life of the country since the last Royal Commission reported 62 years ago.

Old industries have shrunk and new ones emerged. Processes of production have been revolutionized, old crafts disappearing and new skills emerging. With the continuing growth in the size of industrial units and the amalgamation of companies there has developed a managerial society in which ownership has become divorced from control. 
The running of large businesses is in the hands of professional managers, responsible to boards of directors. Trade unions have increased their membership from less than $2 \frac{1}{4}$ million in 1906 to more than 10 million in 1966 , and the membership has been increasingly concentrated in a comparatively small number of large and powerful unions.

These accessions of strength have resulted in the widespread extension of collective bargaining. Trade unions are also consulted by the Government of the day in a large range of matters and provide representatives who serve on many official bodies, committees and tribunals. Employers' associations are similarly recognized.

The Government's involvement in economic affairs has been extended by the nationalization of a number of basic industries, and the acceptance of full employment as an objective of Government policy has brought more detailed and continuous central management of the economy. More recently, Governments have accepted the further responsibility of promoting a prices and incomes policy whereby money prices and incomes should be prevented from running too far ahead of increasing productivity.

Legislation now provides a whole range of services which not only give greater social security than before, but have also helped to modify the class structure of society. This process has, in addition, been fostered by the erosion of some of the distinctions between manual and white-collar employment, and by successive reforms of the educational system.

\section{Membership of Trade Unions and Employers' Associations}

The total working population of the United Kingdom (mid-1967 figures) is almost 26 million, of whom $233 / 4$ million are employees, 15 million of them male and $83 / 4$ million female. More than 14 million employees are manual workers and more than 9 million white-collar workers.

At the beginning of the present century there were 1,323 trade unions of employees with a membership of 2,022,000 workers. At the end of 1966 there were 574 unions with a total membership of 10,111,000, varying in size from the Jewish Bakers Union with 24 members to the Transport and General Workers' Union with $1,482,000$.

The Department of Employment and Productivity lists about 1,350 employers' associations, ranging in size from the Engineering Employers' Federation which covers 4,600 separate establishments with more than two million employees, to small organizations covering section of a trade in one locality. Many of these are, however, local associations subordinate to industry-wide federations of which they are members.

\section{The System of Industrial Relations}

Britain has two systems of industrial relations. One is the formal system embodied in the official institutions. The other is the informal system created by 
the actual behaviour of trade unions and employers' associations, of managers, shop stewards and workers.

The keystone of the formal system is the industry-wide collective agreement in which are supposed to be settled pay, hours of work and other conditions of employment appropriate to regulation by agreement. The informal system is often at odds with the formal.

Actual earnings have moved far apart from the rates laid down in industrywide agreements, and the gap between the two continues to grow. At the same time, disputes procedures laid down in industry-wide agreements have been. subjected to strain by the transfer of authority to the factory and workshop.

Bargaining which takes place at factories is largely outside the control of employers' associations and trade unions. It usually takes place piece-meal and informally, and results in competitive sectional wage adjustments and chaotic pay structures. These developments help to explain why resort to unofficial and unconstitutional strikes and other forms of workshop pressure has been increasing.

The decentralisation of collective bargaining has taken place under the pressure of full employment, which in Britain has had special consequences because of the way industrial organizations have reacted to it. The authority of employers' associations has declined, but despite this decline most individual companies do not have comprehensive and well-ordered agreements for regulating terms and conditions over and above the industry-wide minima. Moreover many companies have no effective personnel policy to control methods of negotiation and pay structures, and perhaps no conception of one.

\section{Multi-unionism in Industry}

Trade unions have, like employers' associations and managers, helped to sustain the facade of industry-wide bargaining, but cannot bear primary responsibility for the decline in its effectiveness. However, certain features of trade union structure and government have helped to inflate the power of work groups and shop stewards. One is the existence of multi-unionism in most British factories and industries.

Most of those who conduct industrial relations in Britain are content with things as they are, because the arrangements are comfortable and flexible and provide a very high degree of self government. Existing arrangements can be condemned only because these important benefits are outweighed by the disadvantages - the tendency of extreme decentralisation to degenerate into indecision and anarchy, the propensity to breed inefficiency and the reluctance to change.

The Commission states that any suggestion that conflict between the two systems of industrial relations can be resolved by forcing the informal system to comply with the assumptions of the formal system is unrealistic.

\section{The Reform of Collective Bargaining}

The central defect in British industrial relations is the disorder in factory and workshop relations and pay structures promoted by the conflict between the formal 
and informal systems. The remedy must seek to introduce greater order into factory and workshop relations.

This cannot be accomplished by employers' associations and trade unions working at industry level or by industry-wide agreements. A factory-wide agreement (or a company agreement), however, can regulate actual pay, constitute a factory (or company) negotiating committee and a grievance procedure which suits the circumstances and deal effectively with other matters (such as the regulation of hours actually worked and work practices) which industry-wide agreements cannot in most industries deal with effectively.

If the basis of British industrial relations is to become the company or factory agreement, the change must be accomplished by boards of directors of companies.

The commission recommends that boards of companies should review industrial relations within their undertakings. They should aim

- to develop comprehensive and authoritative collective bargaining machinery at company and/or factory level

- to develop joint procedures for the rapid and equitable settlement of grievances in a manner consistent with the relevant agreements

- to conclude agreements regulating the position of shop stewards

- to conclude agreements covering the handling of redundancies

- to adopt effective rules and procedure governing discipline

- to ensure regular joint discussion of measures to promote safety at work.

In pursuit of these objectives companies should welcome the exercise by employees of their right to join a trade union, develop positive management policies on specified matters, such as recruitment, promotion, training and retraining, and collect systematic information on which to base action, making available to workers' representatives such information as they may reasonably require.

Employers' associations should support and assist companies in conducting their reviews, and should join with trade unions in considering what amendments may be necessary in industry-wide agreements to facilitate effective collective bargaining in the company and the factory.

Industry-wide agreements should be confined to matters which they are capable of regulating. They can provide guidelines for satisfactory company and factory agreements.

\section{An Industrial Relations Act}

Recent developments show that some companies and employers' associations are moving in the direction indicated, and that trade unions are for the most part willing to move with them, but the pace of change is by no means sufficient to 
meet the country's needs. Given the need and magnitude of the change it is impossible to be confident that voluntary action alone will achieve what is required in time.

- What is needed first of all $»$, the report says, a is a change in the nature of British collective bargaining, and a more orderly method for workers and their representatives to exercise their influence in the factory; and for this to be accomplished, if possible, without destroying the British tradition of keeping industrial relations out of the courts.

To accomplish this an Industrial Relations Act should be passed under which companies will be obliged to register collective agreements with the Department of Employment and Productivity.

This requirement would have a dual purpose - to emphasize that the primary responsibility for the conduct of industrial relations within a concern, and for the framework of collective agreements within which those relations are conducted, lies with the board of directors, and to draw attention to the aspects of industrial relations which the public interest requires should be covered wherever possible by clear and firm company and factory agreements.

Initially, only companies with 5,000 or more employees should be covered, but this limit should be progressively reduced. The Act should apply also to nationalized industries and public services other than the civil service.

\section{INDEPENDENT Commission}

The Act should provide for the establishment of an independent Industrial Relations Commission, with a full-time chairman and other full-time and part-time members. The Commission would, on a reference from the Secretary of State for Employment and Productivity, investigate and report on cases and problems arising from the registration of agreements. The Department of Employment and Productivity's industrial relations service would handle queries and problems to the point where reference was made to the Commission. The Commission should also consider problems referred to it about companies not large enough to be covered by the obligations to register agreements, as well as carrying out inquiries into the general state of industrial relations in a factory or industry.

\section{Novel Task}

The report does not set out any detailed rules to which the commission would be expected to work. It would be entrusted with a novel task, and would, therefore, have to develop its own rules and methods in the course of its work. It is suggested what the principles which guide the commission's work might be. Failure by a company to register its agreements, or to report that it has none and why, would render it liable to a penalty.

"The intention of the Act n, states the report, is to promote the reform of industrial relations by establishing a system of registration which will enable society's expectations in the field of industrial relations to be brought home clearly 
and unambiguously to the boards of companies and to trade unions; and which will make sure that they are given adequate assistance in meeting those expectations. W'e do not think the shortcomings of our existing industrial relations are due to malice or moral weakness on the part of employers, managers or trade unionists. They are primarily due to widespread ignorance about the most sensible and effective methods of conducting industrial relations, and to the very considerable obstacles to the use of sensible and effective methods contained in our present system of industrial relations.

The change would demand a great deal from companies, employers' associations, trade unions, shop stewards, managers and supervisors. "But ", adds the report, the consequences of failing to reform our system of industrial relations are far more alarming than the consequences of the Act. »

\section{Aid to Working of Incomes Policy}

The results of the Industrial Relations Commission's work would assist the working of incomes policy. The registration of company and factory agreements would provide far more information about the decisions which affect pay than is at present available, and would expose the whole process of pay settlement to the influence of policy.

The proposals in the report for the reform of collective bargaining cannot of themselves put an end to * bidding up * for labour by employers or \& leap-frogging * tactics by trade unions, but the present system of bargaining permits both to occur without any possibility of national control because companies themselves cannot exercise control.

< Our proposals », says the report, « are designed to provide effective control of industrial relations, including pay, at the level of the factory and company, by means of properly conducted agreements between companies and trade unions. If the decisions companies and trade unions take accord with incomes policy, then incomes policy will work.

\section{Extension of Collectrve Bargatning}

While the first task in the reform of British industrial relations is, the report states, to bring greater order into collective bargaining in the company and plant, the second is to extend the coverage of collective bargaining and the organization of workers on which it depends. Freedom of association and trade union recognition, Wages Councils and compulsory arbitration all have a bearing on the question, and these are examined by the report.

- We consider that it is contrary to the public interest », says the Commission, * that an employer should stipulate in a contract of employment that an employee is not to belong to a trade union : and that any such stipulation should in law be void and of no effect. We except from the scope of this recommendation employment in the police and in the armed forces of the Crown.

The Commission also holds that it is foreign to the purposes of a friendly society that it should prescribe in its rules that no one can be a member and 
draw benefits if he is a trade unionist, and it recommends that it should be provided that no friendly society should have such a rule. The Commission envisages that problems of trade union recognition would be dealt with by the Industrial Relations Commission.

It is recommended that the Wages Council Act should be amended with the object of encouraging the development of voluntary arrangements. The requirements relating to the abolition of wages councils should be eased and wages inspectors enabled to enforce statutory minimum rates for a limited period after abolition.

\section{Unilateral Arbitration on Selective Basis}

On the question of compulsory arbitration the Commission sees a useful role for unilateral arbitration to support the work of the Industrial Relations Commission, where for example an employer rejects a recommendation that he should grant recognition to a union or unions.

It is therefore recommended that unilateral arbitration should be available for use on a selective basis, its use being confined to circumstances where it can contribute to the growth or maintenance of sound collective bargaining machinery. It envisages that the Industrial Court would be the arbitration body.

Referring to incomes policy and the work of wages councils and arbitrators, the commission says that the only long term solution to the problems of the former is the extension of voluntary collective bargaining to their industries.

In the short run it is for the Government, after reviewing such possibilities as a national minimum wage or the fixing of statutory minimum earnings for broad groups of industries, to formulate and state in clear terms what its policy is in relation to the lowest paid workers and how it is to be pursued.

So far as arbitrators are concerned there should be legislation placing on them an obligation to take incomes policy into account. They should also be encouraged to give reasons for their awards.

\section{EFficient Use of Manpower}

Studies made and results achieved in Britain confirm that there is subtantial room for improvement in the efficiency with which labour is used, and this represents not only a chalenge, but a major opportunity.

Most of the practices which result in serious waste of manpower, it states, can be understood only in relation to particular circumstances in particular undertakings or plants. Many are simply the result of changed circumstances and technological advance, and work groups seek their retention as a means of protection.

But it is totally misleading to suggest that the primary responsibility for the wasteful use of manpower in this country rested either on workers or on trade unions. Even where restrictive labour practices exist their removal is only one element in securing the efficient use of resources, which is the task of management. 
The Commission rejects the possibility of dealing with restrictive labour practices by means of a tribunal.

The report says that the Commission's proposals for the reform of collective bargaining are fundamental to the improved use of manpower. They will get rid of assumptions and attitudes to collective bargaining which have allowed restrictive labour practices to grow and efficiency to languish. They will put in management's hands an instrument - the factory agreement - which, properly used, can contribute to much higher productivity. The work of the Industrial Relations Commission can give an impetus to change and progress which has been significantly missing hitherto. The direct benefits will be felt not only by employers but also by their employees, and indirectly the community as a whole will gain. That this is so underlines the urgency of the need for reform.

Training, says the Commission, is an area in which restrictive traditions have especially deep roots in British industry and where the presence of technological change makes the need for a radical change in outlook particularly urgent.

Certain specific obstacles in the way of access to skilled work must be removed. - Dilution * agreements should be revised and a revolution in attitudes and practical performance is needed in the training of women.

There is urgent need to secure the rapid and general adoption of systems of training which accord with the social and economic needs of a modern industrial society, with the following basic features : the laying down of objective standards by which to judge qualifications; a person who has attained those standards to be universally accepted as qualified and eligible to do the work in question; apart from introductory training and further education for young people, the content and duration of training courses to be determined by what is required to enable trainees to reach the set standards; no artificially restrictive barriers to be placed against access to training, for example on grounds of age, sex or colour.

Once objective standards for judging qualifications have been laid down, trade unions should revise their rules to ensure that no qualified worker will be arbitrarily denied admission or the right to use his skills, and any worker alleging that he has been denied admission although qualified should have the right of appeal to an independent review body.

There is a long way to go before the principles and practices in training have been transformed in the way they ought to be. What is required is a sustained attack on outworn ideas and groundless preconceptions at all levels. Aided by the other Departments concerned, the Department of Employment and Productivity will have to take the major responsibility for rousing the country to the gravity of the issues and for carrying through the required reforms in time.

\section{Struxks AND OTHER INDUStrat ACtion}

Official strikes tend to be much more serious individually than unofficial strikes, but they are relatively infrequent and their number shows no consistent tendency to grow. About 95 per cent of stoppages are unofficial, and unofficial 
strikes are becoming more common. About half concern wages and more than 40 per cent * working arrangement, rules and discipline $\$$ and * redundancy, dismissal, suspension, etc. , matters usually dealt with at the workplace rather than at industry level. Because of their unpredictability unofficial strikes have a damaging effect on managerial initiative and the economic consequences are obvious and serious.

The possibility of introducing a new procedure for dealing with stoppages creating grave national loss or widespread hindrance to public health and safety is rejected by the Commission as not being superior to the existing flexible procedures so also is the possibility of making strike ballots compulsory.

\section{Examining Long-term Problems}

The tendency to appoint inquiries into industrial relations problems which are able to examine long-term problems as well as immediate causes of dispute is welcomed, but in future the resources available io the bodies concerned will need to be increased. The Department of Employment and Productivity should have its own industrial relations research section.

While the Industrial Relations Commission would normally be given responsibility for carrying out inquiries into long term problems of industrial relations it is desirable that the Secretary of State should still be able to appoint ad hoc inquiries.

The Commission proposes that existing powers should be widened to enable the Secretary of State to place on an industrial relations officer the duty of obtaining full facts about unofficial strikes in an industry, region or undertaking where they are causing difficulty.

\section{Dealing with the Causes of Unofficial Strikes}

- By far the most important part in remedying the problem of unofficial strikes, and other forms of unofficial action, will $»$, says the Commission, \& be played by reforming those institutions of whose defects they are a symptom... Our proposals for reforming the collective bargaining system are, therefore, fundamental to the solving of this problem also. "In addition a number of the Commission's recommendations will have an important effect on certain specific causes of strikes - recognition disputes, for example, and dismissals alleged to be unfair.

\section{Enforcement of Colnective Agreements}

The Commission examines the implications of making collective agreements into binding legal contracts. That they are not legally binding at present reflects the intention of the parties themselves. If existing agreements were to be made into legal contracts this would have to be done by a statute attaching the force of law to the terms of a bargain contrary to the wishes of the parties. This would be a new departure in the law of contract and a breach with a long tradition in our industrial relations. 
The case for it might be argued if it could be shown to promise a decisive turn for the better in industrial relations, and in particular a substantial reduction in the number of unofficial strikes. But to make the present inadequate procedure agreements legally enforceable would be irrelevant, and would divert attention from, and hinder, action to remedy the real causes. A measure which had the effect of putting on unions a legal obligation to use their best endeavours to secure the observance of procedure agreements would be more likely to lead to internal union disruption than to less unofficial strikes.

In present circumstances no proposal to impose legal sanctions on individuals who strike in breach of procedure is practicable if it relies on enforcement by the employer. Experience shows that criminal proceedings would not be successful.

An \& automatic sanction such as a loss of statutory rights to notice and redundancy pay would not succeed : it would not in fact be automatic but would depend on employer enforcement and would be ineffective for other reasons, as well as being unfair.

The reform of collective bargaining will reduce greatly the problem of unconstitutional strikes, which may not, however, disappear. When reform has taken place, it will then be possible to identify any circumstances in which it would be neither unjust nor futile to apply legal sanctions, because satisfactory disputes procedures will be available and because legal penalties will be a appropriate where irresponsibility or ill-will is the root cause of their breach. The Industrial Relations Commission should be instructed to keep the question of legislation for the enforcement of procedure agreements under review in the light of progress made in the reform of industrial relations in general and of disputes procedures in particular.

\section{Safeguards for Employees Aganst Unfatr Dismissal}

The Commission says that it is desirable that satisfactory voluntary procedures governing dismissals should be developed and extended. With two dissentients, it recommends early legislation to establish statutory machinery to safeguard employees against unfair dismissals. 'This would be framed in such a way as to encourage voluntary action.

Any worker who felt himself unfairly dismissed would have a right to appeal to a labour tribunal seeking compensation or (if both parties agree) reinstatement. Satisfactory voluntary procedures would be exempted from the statutory machinery.

\section{Labour Tribunals}

The Commission considers it desirable to improve the present machinery for the judicial determination of disputes between individual workers and employers arising out of individual contracts of employment and of statutory claims. It recommends that the existing industrial tribunals should be renamed a labour tribunals * and their jurisdiction extended to enable them to deal with such disputes.

The labour tribunals would try to promote the amicable settlement of disputes falling within their jurisdiction by means of conciliation wherever possible. 


\section{Safeguards for Individuals in Reilation to Trade Unons}

The Commission examined the case for and against the closed shop, and comes to the conclusion that the possibility of prohibiting it must be rejected. It is better, it states, to recognize that under proper safeguards a closed shop can serve a useful purpose and to devise alternative means of overcoming the disadvantages which accompany it.

Research shows that it is unlikely that abuse of power by trade unions in relation to individuals is widespread. It does happen, however, and because union membership can affect members' livelihoods, safeguards are needed.

The Commission recommends that an applicant for trade union membership who considers that his application has been arbitrarily turned down should have a right of complaint, and subsequently if necessary to a new independent review body. This would consist of a lawyer as chairman and two members chosen from a panel of trade unionists.

There should also be a right of complaint to the proposed independent review body if a trade union member feels he has been unjustifiably expelled or has otherwise been penalized in such a way that he has suffered a substantial injustice. A right of complaint about alleged election malpractices should also be granted. The requirements relating to the rules of trade unions should be revised to ensure better safeguards for members; the new requirements suggested relate to admission, discipline, disputes between a union and a member, elections and shop stewards. Accounts of the larger unions should be professionally audited and superannuation schemes for members properly valued.

\section{Trade Unions}

The Commission examines the changes in union structure which will be required if unions are to play their full share in the reconstruction of industrial relations.

The Commission makes recommendations for reducing problems of multiunionism. Industrial unionism is ruled out. There is scope for many more mergers between unions, particularly in engineering, construction and printing.

The report also recommends the conclusion of inter-union agreements on rights of representation, intensification by the T.U.C. of its efforts encourage unions to adopt closer working arrangements, and the adoption by the T.U.C. of the principle of ane union for one grade of work within one factory as a guide for the future development of structure.

Trade unions organizing in multi-union situations should provide constitutionally recognized committees to carry out many of the functions now carried out by unofficial shop stewards « combine $>$ committees.

The processes of union government should be altered to accommodate shop stewards and work groups more adequately. It is desirable for union branch 
organization to be based on factories and for branch meetings to be held at the place of work. Union rules about shop stewards need to be revised.

More full-time union officials will be required, and unions are urged to develop training courses for junior full-time officials and for shop stewards; in the case of the latter day-release courses with the employer's co-operation offer the best prospects.

Trade unions which do not already collect subscriptions by means of the checkoff might usefully consider doing so, and employers should consider requests for it sympathetically.

It is suggested that the T.U.C. should give a lead in all these matters, and that it will need to develop and adapt its organization to cope satisfactorily with the many new aspects of its work.

\section{EMPLOYens' Associations}

- The central responsibility of employers' associations in the reconstruction of industrial relations is , the Commission states, « to promote and support effective and comprehensive agreements in the factory and company. A Any rules which obstruct effective collective bargaining should be amended. Attitudes are already changing, but what is needed is a rapid increase in scale and pace of the change,

It is hoped that the C.B.I. and the employers' associations will consider their attitudes on union recognition, especially where white-collar unions are concerned, with a view to encouraging the development of collective bargaining.

It is suggested that the Engineering Employers' Federation should establish a national division to which multi-plant companies can affiliate direct. Other major employers' associations may also have to revise their constitutions and procedures to give adequate recognition to individual companies. Organizations which act both as employers' associations and trade associations have advantges which others which others should carefully consider.

There is a strong case for amalgamations among smaller associations, and the C.B.I. should consider widening its scope to include companies at present excluded from membership.

\section{Changes in the Law}

The Commission recommends that the law relating to labour relations and trade unions and employers' associations should be codified or that if this is considered premature a comprehensive consolidating measure should be enacted as soon as possible after legislation to implement the report. A special Industrial Law Committee should be attached to the Industrial Relations Commission to keep the law under review.

It is proposed that trade unions and employers' associations should in future have separate legal definitions, and that they should be granted corporate personality and register upon a new Register of Trade Unions and Employers' Associations. 
The immunities from criminal prosecutions and civil actions given to persons in respect of acts committed in contemplation or furtherance of a trade dispute which are contained in the Conspiracy and Protection of Property Act 1875 and the Trade Disputes Act 1906 should be made expressly applicable for the benefit of trade unions and registered employers' associations. The Trade Disputes Act 1965 should also remain in force.

A majority of the Commission recommend that s. 3 of the 1906 Act, which prevents an action being brought against any person (or combination) for an act done in contemplation or furtherance of a trade dispute on the ground only that it induces some other person to break a contract of employment, together: with the relevant provision of the 1965 Act, should no longer apply to persons and combinations other than trade unions and registered employer' associations. The protection of s. 3 of the 1906 Act should however cover inducement of a breach of any contract, including a commercial contract, and not only a contract of employment.

A majority of the Commission recommend that s. 4 of the Trade Union Act 1871, which precludes the direct legal enforcement of various kinds of trade union agreement, should be repealed.

The provisions as regards picketing contained in s. 2 of the 1906 Act should be amplified to make lawful the peaceful persuation of customers not to deal with an employer in dispute.

The general immunity enjoyed by trade unions from actions in tort under s. 4 o fthe 1906 Act should in future be confined to torts committed in contemplation of furtherance of a trade dispute.

Changes are recommended in s. 22 of the National Insurance Act 1965, which concerns the disqualification of persons for receipt of unemployment benefit when there is a trade dispute at their place of employment. A claimant for benefit should no longer have to prove that he is not a member of a \& grade of class * of workers, any of whom are participating in or financing or directly interested in the dispute. Nor should a claimant be regarded as a financing » a trade dispute simply because he is a member of a trade union paying strike pay to those on strike.

\section{Workers' Participation in Management}

The importance of the question of workers' participation in management for industrial relations is acknowledged, though any changes to encourage such participation should be subsidiary to reforms in collective bargaining. However, a majority of the Commission feel unable to recommend the appointment of «workers' directors' to boards of companies. If a profit sharing and co-partnership scheme is to play a part in the wage structure of an undertaking, this should be settled by negotiation. 